DOI: 10.17951/lrp.2018.37.2.41-50

\author{
Oresta Karpenko \\ Drohobych Ivan Franko State Pedagogical University \\ ORCID: http://orcid.org/0000-0003-1841-882X
}

\title{
FORMATION OF A PRESCHOOLER'S SPIRITUAL PERSONALITY THROUGH THE PRISM OF UKRAINIAN PEDAGOGY
}

\begin{abstract}
In the history of Ukrainian pedagogical thought, the problem of formation of a preschool child's spiritual personality is given special attention. There are different approaches to the study of concepts, content and principles of spirituality, the spiritual world of an individual, spiritual and moral values. Spiritual values and priorities of society arise from cultural and historical traditions, the experience of the nation. The content of such dissimilar categories as "spirituality" and "cordiality" has been studied. Spirituality expresses orientation of a human being toward the transcendent, whereas cordiality is defined by kindness in respect of people. Spiritual values are monitored and supported by public opinion and human conscience which helps normalize relations, brings order to and maintains harmony in society. The main task of educators is to instill moral self-awareness in every child and teach it spiritual values. Program requirements include promotion of spiritual ideas about the spiritual ideal, enrichment of emotional experience and formation of a certain self-attitude. Formation of spiritual basics must begin in the first years of life. In preschools, components of spiritual education are implemented through various forms of educational work.
\end{abstract}

Keywords: spirituality, spiritual values, preschool children, content of spiritual education, Ukrainian pedagogical thought

The problem of personal development, education of an ultimately spiritual individual guided by Christian values does not lose its topicality. A priority task of reforms in Ukrainian preschool education is a full development of a child's personality, including its spiritual sphere. Today, children have involuntarily become witnesses of hard times, when life is undergoing complex changes and stereotypes break down and when established moral principles are exposed to a negative influence 
of human vices such as cruelty, violence, brutality. It is only natural that such developments cause concern and anxiety.

The spiritual renewal of society occurs when souls are restored, when each individual is ready to battle poor qualities like infamy, lie, servility, vanity, consumerism, violence. The generation of today faces multiple challenges as the downturn in economy leads to moral degradation, growing incivility, irresponsibility, violence, and sometimes absolute intolerance and resentment in relationships between people. Therefore, spiritual rejuvenation aims at instilling moral habits and values in the younger generation such as truthfulness, sensitivity, kindness, benevolence, honesty, loyalty, generosity, dignity, humanity, compassion, etc.

\section{THE DEFINITION OF SPIRITUALITY}

Spirituality is one of the most important factors in the development of civilization, the discovery of new social norms which comply with the ever-changing conditions. The scholarly literature offers different approaches to the study of concepts, content and principles of spirituality, the spiritual world of an individual, spiritual and moral values. Cordiality is often derived from spirituality (Dubichynskyj 2006, p. 12). The latter is linked to the need of knowledge (of the world, oneself, the meaning of life). Spirituality is defined by contemplation of these issues and attempts to find the answers. Objective benefits of human spiritual activity coincide with subjective altruism. This activity is important to enjoy the process of perception of the world.

Spirituality is "a category of human existence consisting in its ability to create oneself and the culture". Spirituality is

(...) the highest level of personal development, where the main motivational and sense determinants are the highest human values. This is the highest level of mature and responsible (for himself and others) person, capable of not only learning and reflecting the outside world, but of creating it (Kremen 2008, p. 244).

Spirituality is orientation of an individual toward selected goals, an axiological summary of consciousness; definition of life in the quest for knowledge of the world and especially oneself, in search of answers about right and wrong.

The category of "spirituality" is related to the category of "cordiality". These categories have a different orientation. Spirituality expresses orientation of a human being toward the transcendent, while cordiality is defined by kindness in respect of people. Spirituality and cordiality are the underlying strategies of human life that form the basis of personality (Kremen 2008, p. 245). 
The concepts of spirituality and morality are not identical. T. Tyurina believes that morality and spirituality are different levels of personality development.

(...) Morality involves orientation of a person, first of all, toward socio-historical norms and values, assessment of particular individuals or the community in general. An important task of moral education is to teach one to live among people in compliance with the rules and regulations adopted in the society, i.e. to adapt a person to life in society. Spirituality is a person's ability to be free, independent and self-sustaining. Since moral criteria operating in society are of relative nature, a highly spiritual person makes decisions based on the universal understanding of the good, kindness, truth, taking into account his own spiritual "Self", strong awareness of purpose and meaning of his life (Tyurina 2005, p. 133).

Spirituality is the internal foundation of a person which sets him apart as an individual, reflects creative orientation, discloses interests, needs, preferences.

Spirituality, according to L. Buyeva, is a matter of sense acquisition. Spirituality indicates a hierarchy of values, goals and content (Buyeva 1999, p. 65). Morality is a variable form of social consciousness and unwritten laws that consists of a set of social values and norms which help distinguish between the good and evil and expresses the ideals of human life, the vision of the past, present and future. Morality is an area which serves as a socially significant structure of values, priorities, rules of conduct recognized by humankind (Andrushzchenko 2006, p. 573). Morality is a "system of beliefs and ideas, norms and values that govern moral behavior. Morality performs cognitive, evaluative, educational functions" (Shchynkaruk 1986, p. 399).

O. Sukhomlynska connects spirituality to the sphere of culture. She believes that spirituality is a complex psychological phenomenon of self-identity, internal perception, appropriation and humanization of culture and integration into it, understanding of culture as a personal legacy (Sukhomlynska 2002, p. 14). Spirituality is one of the most common, borderline characteristics of a person and his life. Therefore, it cannot be defined conventionally - only general contours such as the ability and need to be oriented in life, higher universal values of Truth, Goodness and Beauty in their unity can be determined by genus and species characteristics. In this sense, spirituality serves as an ideal to which humanity and an individual aspire in their spiritual self-improvement. We share the above-mentioned view as well as the assertion where a person is seen as a spiritual entity on condition that he acts accordingly. 


\section{PRESCHOOLERS' SPIRITUALITY FORMATION MECHANISMS}

Spirituality of a person develops in the process of moral activity. The moral analysis and generalization of the phenomenon encourage a child to actively engage in manifestations of the mind and senses. The spiritual activities are active efforts of an individual to transform moral values of society - ideas, attitudes, beliefs, ideals - into personal resources, intrinsic values, norms and rules of behavior. In this sense, it is particularly important for preschoolers to make active efforts in search of the ideal. "Real education implies constant mental and spiritual activity of the mind and the soul; moral values revealed to the pupil by the teacher become his personal property, come out in his relationship with friends, other people" (Sukhomlynskyi 1976a, p. 259).

V. Sukhomlynskyi emphasized that a child who feels for another person becomes friendly. Affection, kindness, and warmth nurture a child's soul. For a child to acquire a rich spiritual world it is important to use such methods and techniques that will show how to overcome difficulties, evoke emotions such as dignity, honor, self-respect (Sukhomlynskyi 1976a, p. 222).

The mechanism of formation and functioning of spirituality is conditioned by the coordinate system of human living space. Today, it is no longer viewed in the context of tradition or religion (Kremen 2008, p. 243). Spiritual formation is a formation of individual expressiveness of a person and social needs in the motivational system. The ultimate goal is to create demand for knowledge, the social goal is to create the need for living and assisting to others.

Ancient thinkers singled out physical hardening of personality, formation of mental and moral qualities. Aspiration, will, and desire, according to Aristotle, are inherent even in newborn children, while reasoning and common sense manifest themselves only with age. Therefore, care for the body precedes care for the soul, and only then should one take care of talents and inclinations. This will nurture the mind, while the care for the body will nurture the soul.

For the first time in the history of educational thought, spiritual education was mentioned in V. Monomakh's Edification of Children:

(...) Honour seniors, as your father, the young, as your brothers, do not laze in your home, but take care of everything: do not rely on a ciwun or an adolescent, so that you are not mocked by those who come to you, and your home and your meal is not mocked (Borisova, Kuzmenko 2004, p. 74).

The driving force of human activity, according to H. Skovoroda, is a thought. Therefore, the human mind is primarily subject to education. The thought governs 
the body. But rational thinking and knowledge are not enough, because knowledge itself does not yet constitute a virtue. The acquisition of knowledge should be combined with the formation of high moral qualities, without which education is artificial and false. Proper education is the unity of truth and virtue, knowledge and high moral aspirations.

Another object of education is the human heart. If the cultivation of mental faculties appeals to the intellect, fostering moral character addresses the heart. According to Skovoroda, we must cultivate honesty, moderation, industriousness, temperance, disdain for worldly temptations of wealth, fashion, hypocrisy. An equally important element is cultivation of the will as well as the unity of thought and action, the word and the deed. This promotes the need for development and strengthening of the will which helps people follow a reasonable course in their activities.

I. Ohienko emphasized that the implementation of spiritual and national education shapes the main components of an individual's spiritual world such as national psychology, national character and temperament, the national mindset, Christian ethics, folk aesthetics, folk law awareness, national philosophy, spiritual and national worldview, national ideology (Ohienko 1994, pp. 37-38).

Of importance for spiritual formation is the study of God's Law. Summarizing the creative achievements of teachers in Germany, England, or America, S. Rusova believed that religious instruction is very useful for raising moral sense (Rusova 1996, p. 216). Preschool children should receive basic notions about God, His existence, moral and ethical principles to guide them in life. Children need to understand religion as a reflection of the world in a complex, often contradictory spiritual life.

The concept of spiritual and moral education defines the connection between the spiritual culture of society and the process of education, because the category of spirituality is directly linked to the need of understanding (the world, oneself, the content and purpose of life). A person is spiritual to the extent he reflects on the issues of peace and harmony between the higher values and spiritual culture of mankind, on the one hand, and the human inner world, on the other. A person is spiritual to the extent he carries out inner work to create this harmony.

Extremely important tasks which aim at spiritual rejuvenation of society lie in cultivation in the younger generation of such moral virtues as truthfulness, sensitivity, kindness, benevolence, honesty, loyalty, generosity, dignity, humanity, compassion and others. Sukhomlynskyi believed that "the only way to become a moral person was by letting conscience, shyness, responsibility and duty into one's heart" (Sukhomlynskyi 1976b, p. 261). 


\section{THE CONTENT AND TASKS OF SPIRITUAL EDUCATION OF PRESCHOOL CHILDREN}

The content, forms and methods of spiritual and moral education of an individual found coverage in the works of modern scholars: I. Bekh, A. Bogush, T. Hrytsiv, O. Kononko, V. Panchenko, M. Chepil and others. Formation of a child's social experience in the process of education should be of humane character in order to promote principles of spiritual identity. By integrating moral, spiritual and social aspects, the process of education focuses on the holistic development of an individual in harmony with the world and himself.

Spiritual values are controlled and supported by public opinion and human conscience which makes it possible to normalize relations, bring order to and maintain harmony in society (Bekh 2005, p. 3). The main task of teachers is to cultivate a child's moral self-awareness and spiritual values.

Spiritual education means being close and ready to help identify the sin (Skrypnyk, Sushok 2012, p. 8). The concept of sin in Greek means "missing the target". Throughout life, we try to shape ourselves. Since the shaping of the soul starts in early childhood, a child may often need an assistant. Thus, education commences at preschool age and it lays the foundation on which a large building - a child's soul - will later stand. To educate a conscious citizen, it is important to work a lot with preschool children. Metaphorically speaking, it is removing the silt from a blooming meadow called "Ukraine". And the next step is shaping human consciousness.

Formation of spiritual basics during the first years of life is provided for by preschool education programs: "Child", "Sunflower", "Ukrainian Preschool". The program requirements include promoting the absorption of spiritual ideas about the ideal person, enrichment of emotional experience and formation of a certain attitude to oneself. Teachers should inform preschool-age children that negative actions called "sins" are normally criticized and teach children to behave in accordance with moral standards, to be able to assess their own negative deeds, to form a negative attitude to bad behavior in general.

A complex regional program of preschool children's development - "Ukrainian Preschool" - aims to expand the content of educational work with children between two and six years of age, taking into account the ethnic, historical and socio-cultural features of Western Ukraine (Bilan, Vozna 2012, p. 7). Social and moral development of preschool children includes laying the foundations of moral 
qualities. At this age, moral sense and knowledge couple with a sense of duty, "the internal moral authority" springs to existence; children choose to behave in accordance with moral standards not because adults demand it, but because it provides them with a sense of complacence. The chapter "On Spiritual Education" sets the following tasks:

- to promote the adoption of ideas about the spiritual ideal, enrichment of emotional experience and development of a certain self-attitude; to teach that negative actions are criticized and called "sins"; a sin is a bad and dishonest act; in our speech, we often use such phrases as "to sin", i.e. to violate cohabitation norms, "to take a sin upon oneself", i.e. to do something contrary to one's conscience, "to fear the sin", i.e. to be afraid of doing bad things; to teach to behave in accordance with moral standards, to be able to assess own negative deeds, to form a negative attitude to bad behavior in general;

- to teach children the immemorial rules: one must not disobey parents, older people, deceive them, mock at the old, make fun of the crippled, torture animals, play the hypocrite, abuse others, cajole, take other people's things without permission, be indifferent to the suffering of others; to give an idea of religious norms underlying human relationships such as kindness, honesty, fairness, respect, responsibility, compassion; to develop an ability to put oneself in other people's place, not to express negative judgments towards peers and younger children; to be able to see positive qualities in children;

- to teach boys to be compliant, tactful and considerate toward girls; to explain the meaning of tolerance (the ability to treat patiently the habits of others, accept the opinions of children, adults);

- to teach to adequately respond to antisocial behavior, resolve disputes, be fair, conscientious and responsible (Bilan, Vozna 2012, p. 190).

The challenge lies in spiritual education which is to bring the child to the understanding of such concepts as God, the universe, life; to familiarize the child with the science of man so that it could understand its purpose and true vocation in life; to prepare the child for acquiring its personal spiritual experience and the interaction with God. This is what can later become a solid basis of true spiritual life.

Spirituality of every child begins at parents' home, through mother's lullaby, grandmother's tales, grandfather's advice, games and entertainment with friends. The plasticity of mind, a great emotional sensitivity contributes to the development of moral feelings, makes preschool age the crucial period of life for the formation of moral principles. The moral education of children is necessary for improving society. Therefore, the problem of spiritual and moral education of the child under school age is important and has an undeniable practical value. 
From the early childhood, a child tends to take after adults. It is important to persuade preschoolers that their lives should be filled with universal moral content based on cultural and national education and religious virtues such as faith, moderation, humility, innocence, or respect for an individual. The child, its soul deeply experiences the joy of doing the good for other people. If the spiritual and moral education is reinforced with good guidance and encouragement to good deeds, inner resources which limit the desires and fastidiousness find their way to a child's heart from the early age. And this is very important for identity formation.

In modern life, the concept of good, conscientious and merciful have depreciated, while material welfare is seen as the highest value. Adults pay great attention to the development of intellectual and physical abilities of their children, while the spiritual aspects of development are regarded with disfavor. After all, a man is not only a physical but also a spiritual being, and he is prone to spiritual formation. To combine the personal and the national, the earthly and the heavenly, the physical and the spiritual is a basic human need. Components of spiritual and moral education (human, national, family values) are implemented in preschools through various forms of educational work.

An important role in the spiritual development of an individual is that of volitional efforts. They inhibit egoistic impulses which prevent the formation of humanity. A crucial part of an individual's spiritual life is defied by his awareness of his willpower and conscious control over it. Volitional efforts, as active manifestations of thoughts and feelings, are formed when a child is convinced that the work that it does has no limit, when it sees the prospect of a more challenging task (Sukhomlynskyi 1976b, pp. 219-220).

Will is a mechanism that makes it possible to control own behavior, mental processes and motivation. Will reflects self-oriented human activity which does not involve the outside world or other people. Volitional regulation of behavior is characterized by deliberateness which is realized through a program goal, a conscious choice of actions from the list of all possible, evaluation of obstacles on the way to the goal, the need to mobilize the willpower to overcome the obstacles. Thus, consciousness, moral ideals and will are powerful motivating forces which define an individual's spiritual activity.

To teach a child that God is a loving Father and that it is a child of God is a challenge of spiritual education which should be faced in early childhood. The mentor's actions, his worldly wisdom, not mere words, teach children to get inspiration from the source of human existence and be thankful to God. This makes a spiritual person; a good seed that will yield good fruit.

One of the crucial factors for the spiritual formation is nature, the music of life. From the young age, a child draws knowledge and spirituality from it, learns 
to protect nature, multiply its beauty and wealth. Only a human is given the ability to assess and understand the value of nature which is amazingly beautiful but extremely vulnerable, too.

The problem of shaping spiritual personality has long been one of the priorities of the Ukrainian pedagogy. The works of Ohienko, Rusova, Sukhomlynskyi and others dwell on the content, mechanisms and factors of spirituality formation in preschool children. In childhood, foundations of spiritual formation of personality, its spiritual and moral feelings, ethical values and love for all living things are laid. This is the period when a child discovers humankind and society; acquires the knowledge of God and life on Earth in all its aspects. This is the first step in personality formation, when a child starts shaping its character and attitude towards the world, people and itself; when the moral standards of behavior important for psychological development are learned. Religious education should go along with moral upbringing. This is a continuous process which begins at birth and lasts a lifetime and aims at mastering the rules and norms of behavior.

\section{REFERENCES}

Андрущенко, В., 2006, Організоване суспільство. In: Проблема організащіі та суспільної самоорганізації в період радикальних трансформацій в Украйні на рубежі століть: досвід соціально-фбілософського аналізу. Київ: Атлант ЮЕМС.

Бех, I., 2005, Вчинок у морально-духовному розвитку особистості. «Дошкильне виховання»", № 2, pp. 3-6.

Білан, О., Возна, Л., 2012, Українське дошкілля: програма розвитку дитини дошкільного віку. Тернопіль: Мандрівець.

Борисова, 3.Н., Кузьменко, Н.У. (ред.), 2004, Хрестоматія з історії дошкільної педагогіки. Київ: Вища школа.

Буева, Л., 1999, О изенностях духовной культуры. Санкт-Петербург: Питер.

Дубічинський, В.В., 2006, Сучасний тлумачний словник украйнськой мови. Харків: Школа.

Кремень, В. (ред.), 2008, Енциклопедія освіти. Київ: Юрінком Інтер.

Огієнко, I.I., 1994, Наука про рідномовні обов'язки. Рідномовний катехізис для вчителів, робітників пера, духовенства, адвокатів, учнів і широкого громадянства. Київ: Обереги.

Русова, С., 1996, Вибрані твори. Київ: Освіта.

Скрипник, В., Сучок, В. (ред.), 2012, Духовно-моральне виховання дітей дошкільного віку (на основі християнського віровчення). Острог: Національний Університет Острозька Академія. 
Сухомлинська, О.В., 2002, Концептуальні засади формування духовності особистості на основі християнських моральних цъінностей. «Шлях освіти», № 4, pp. 13-18.

Сухомлинський, В., 1976а, Духовний світ школяра. In: Вибрані твори: 5-ти т., Т. 1. Київ: Радянська школа, рр. 200-402.

Сухомлинський, В., 1976b, Як виховати справжню людину. In: Вибрані твори:

5-ти т., Т. 2. Київ: Радянська школа.

Тюріна, Т., 2005, Духовна педагогіка: витоки, сутність і перспективи розвитку. Львів: Сполом.

Шинкарук, В., 1986, Філософський словник. Київ: Українська Радянська Енциклопедія.

\title{
KSZTAŁTOWANIE DUCHOWEJ OSOBOWOŚCI DZIECI PRZEDSZKOLNYCH PRZEZ PRYZMAT PEDAGOGIKI UKRAIŃSKIEJ
}

\begin{abstract}
Abstrakt: W historii ukraińskiej myśli pedagogicznej szczególną uwagę poświęca się problematyce kształtowania duchowej osobowości dziecka w okresie przedszkolnym. Ustalono, że istnieją różne podejścia do uzasadniania pojęć, treści, zasad duchowości, duchowego świata osobowości, duchowo-moralnych walorów. Duchowe walory i priorytety społeczeństwa wyrastają z kulturalno-historycznych tradycji, doświadczenia narodu. W artykule zaprezentowano treść kategorii „duchowość” i „duszewność”, ponieważ posiadają one odmienne skierowanie. Duchowość wyraża skierowanie ludzkiego bycia do transcedentności, a duszewność cechuje dobre traktowanie ludzi. Walory duchowe są kontrolowane i wspierane przez opinię społeczną i sumienie człowieka, co umożliwia normalizację relacji, gwarantuje porządek, pozwala zachować porozumienie w społeczeństwie. Podstawowym zadaniem wychowawców jest moralne uświadomienie dziecku siebie jako osobowości oraz umożliwienie mu przyswojenia duchowych walorów. Wśród wymagań programowych znajdują się: wspieranie rozwoju wyobraźni o duchowym ideale człowieka, wzbogacanie własnego doświadczenia emocjonalnego oraz kształtowanie pewnej „postawy do siebie”. Kształtowanie podstaw duchowości powinno odbywać się już od pierwszych lat życia. Jest to okres poznania człowieka i społeczeństwa, odkrycia Boga przez dziecko, zapoznania się z życiem na Ziemi z całą jego barwnością. To początkowy okres tworzenia własnej tożsamości, podstawowych cech charakteru, stosunku do otaczającego świata, ludzi i siebie, a także przyswajania moralnych norm zachowania ważnych dla rozwoju osobowości, w tym jakości psychicznych. Jest to ciągły proces, trwający przez całe życie, skierowany na przyswajanie przez ludzi reguł i norm zachowania. W przedszkolach idea duchowego wychowania jest realizowana przy pomocy różnych form pracy wychowawczej.
\end{abstract}

Słowa kluczowe: duchowość, walory duchowe, dzieci w wieku przedszkolnym, treść duchowego wychowania, ukraińska myśl pedagogiczna 